\title{
STRUCTURAL CHARACTERIZATION OF THE C4a ANAPHYLATOXIN FROM RAT
}

\author{
Lianxian Cui,* Kfuin Ffrrert $\dagger$ and Tony E. Hugli \\ *Institute of Basic Medical Science, Chinese Academy of Medical Sciences, Molecular Biology, 5 Dong \\ Dan San Tiao, Beijing, China, †Department of Biological Chemistry, The University of Michigan Medical \\ School, Ann Arbor, MI 48109-0010, U.S.A. and †Department of Immunology, Research Institute of \\ Scripps Clinic, La Jolla, CA 92037, U.S.A.
}

(First received 22 December 1987; accepted in revised form 18 February 1988)

\begin{abstract}
The C4a anaphylatoxin was purified from rat sera activated by heat-aggregated IgG. The anaphylatoxin was isolated by a three-step purification procedure and was judged to be homogeneous based on visualization of a single stained band after electrophoresis on both cellulose acetate membrane strips and on 9\% SDS-polyacrylamide gels. Results from Ouchterlony and radioimmunoassay analysis indicated that neither rat $\mathrm{C} 5 \mathrm{~A}$ nor $\mathrm{C} 3 \mathrm{a}$ contaminated the $\mathrm{C} 4 \mathrm{a}$ preparation. Rat $\mathrm{C} 4 \mathrm{a}$ is a glycoprotein cstimated to be $11,000-12,000$ mol. wt and contains 76 amino acid residues representing a mol. wt of 8577 and one oligosaccharide unit of $2000-3000 \mathrm{~mol}$. wt. Rat C4a is weakly active in contracting guinea pig ileum at $0.1-1 \mu M$, which is comparable with the activity of human C4a. Both human and bovine C4a are polypeptides free of carbohydrate while rat and presumably mouse $\mathrm{C4a}$ are glycoproteins. The complete primary structure of rat $\mathrm{C} 4 \mathrm{a}$ anaphylatoxin has been elucidated as follows:

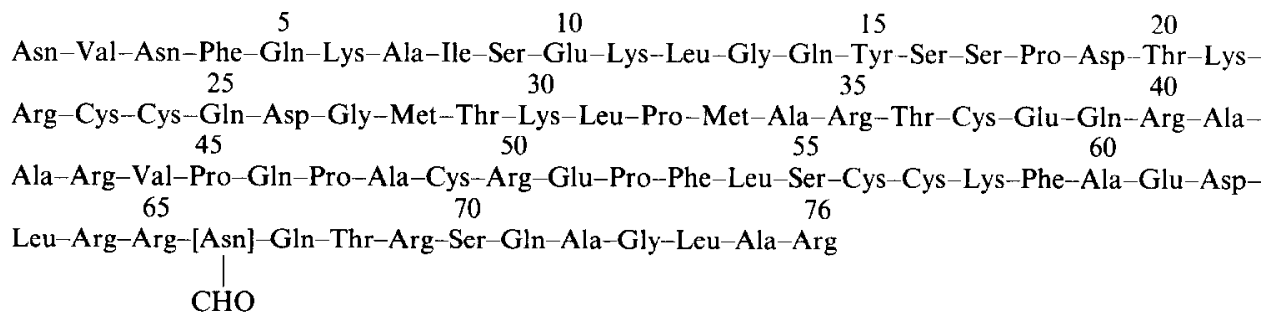

\section{INTRODUCTION}

There are three complement derived anaphylatoxins, identified as C3a, C4a and C5a, and each display a variety of biological activities and have correspondingly distinct chemical characteristics. It has been shown that human $\mathrm{C} 4 \mathrm{a}$ possesses weak spasmogenic activity both for inducing smooth muscle contraction and for enhancing vascular permeability (Gorski et al., 1979). We have suggested that $\mathrm{C} 4 \mathrm{a}$ functions as an anaphylatoxin and is genetically related to $\mathrm{C} 3 \mathrm{a}$ and C5a (Hugli, 1984). Functional studies of synthetic peptides based on the COOH-terminal sequence of human and rat $\mathrm{C} 4 \mathrm{a}$ provide perhaps the most convincing evidence that $\mathrm{C} 4 \mathrm{a}$ is biologically related to the C3a anaphylatoxin (Hugli et al., 1975). Analog synthetic pentapeptides based on the $\mathrm{COOH}$ terminal sequence of human (AGLQR) and rat

Abbreviations: PE-C4a $a_{\text {des Arg }}$, pyridylethylated-C4a $a_{\text {des Arg }}$; PAS, periodic acid Schiff's stain; SDS-PAGE, sodium dodecyl sulfate-polyacrylamide gel electrophoresis; Slp, sex-limited protein is a class II product of the murine major histocompatibility complex and is presumed to arise from gene duplication of the mouse $\mathrm{C} 4$ gene; $\mathrm{CpB}$, carboxypeptidase B; CpY, carboxypeptidase Y; PTH$A A$, phenylthiohydantion derivative of amino acid.
(AGLAR) C4a were 0.05 and $17-25 \%$ as active, respectively, as was a pentapeptide LGLAR from human C3a in the ileal assay (Hugli et al., 1983). Human C4a exhibits spasmogenic activity at levels of $10-20 \mu \mathrm{g} / \mathrm{ml}$ and based on the relative activity of synthetic peptide analogs rat C4a should be considerably more active than human $\mathrm{C} 4 \mathrm{a}$. On a molar basis, human $\mathrm{C} 4 \mathrm{a}$ is less potent in all assays than are either $\mathrm{C} 3 \mathrm{a}$ or $\mathrm{C} 5 \mathrm{a}$ anaphylatoxins.

The primary structure of human C4a (Moon et al., 1981) shows greater homology with C5a than with $\mathrm{C} 3 \mathrm{a}$. However, $\mathrm{C} 4 \mathrm{a}$ is functionally related to $\mathrm{C} 3 \mathrm{a}$ and not C5a based on cross-tachyphylaxis of the guinea pig ileum by $\mathrm{C} 3 \mathrm{a}$ and $\mathrm{C} 4 \mathrm{a}$. Extending the studies of $\mathrm{C} 4 \mathrm{a}$ to the rat system provides new insight into the relationships between structure and function of $\mathrm{C} 4 \mathrm{a}$. Furthermore, since $\mathrm{C} 4 \mathrm{a}$ is generated specifically from activation of the classical complement pathway by antigen-antibody complex interaction with $\mathrm{Cl}$, anti-

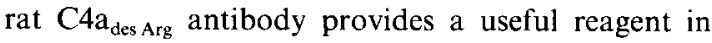
developing immunoassays for detecting $\mathrm{C} 4$ conversion in this popular animal model. An immunoassay for rat $\mathrm{C} 4 \mathrm{a}$ will prove useful in monitoring the course of immunologic diseases that involve the classical complement cascade in the experimental rat model. 


\section{MATERIALS AND METHODS}

Bio-Gel P-60 and QAE Sephadex were oblained from Bio-Rad and Sigma Chemical Company, respectively. The Mono SHR 5/5 column was purchased from Pharmacia. Pooled rat serum was collected from two outbred strains (Wistar and Sprague-Dawley) of male and female animals by the Biotrol Company. The 2-mercaptomethyl-3guanidino-ethylthiopropanoic acid was obtained from Calbiochem, La Jolla. N-Glycanase ${ }^{\mathrm{TM}}$. (peptide: $N$-glycosidase $F$, peptide- $N^{4}-[N$-acetyl-betaglucosaminyl] asparagine amidase) was purchased from Genzyme Corp., Boston, MA. All other reagents and solvents were of the highest chemical purity available.

\section{Bioassay}

Anaphylatoxin activity was assessed by medsuring the contraction of terminal strips of guinea pig ileum (Cochrane and Müller-Eberhard, 1968).

\section{Purification of rat $C 4 a$ and $C 4 a_{d e s}$ Arg}

Two liters of rat serum was activated by adding $1 \mathrm{~g}$ of heat-aggregated $(64 \mathrm{C}$ for $60 \mathrm{~min})$ human $\mathrm{IgG}$ in the presence of $2 \mathrm{mM}$ serum carboxypeptidase $N$ inhibitor, 2-mercaptomethyl-3-guanidino-ethylthiopropanoic acid (Hugli et al., 1982). The activated serum was acidified by slowly adding concentrated $\mathrm{HCl}$ to a final concentration of $1 \mathrm{~N} \mathrm{HCl}$ and the precipitate was centrifuged. The supernatant, containing acid soluble proteins including the anaphyla toxins, was dialyzed against water in a small pore tubing then neutralized to $\mathrm{pH} \mathrm{5-6}$ and lyophilized. Gel fltration of the lyophilized material redis: solved in $400 \mathrm{ml}$ of $0.05 \mathrm{M}$ ammonium formate was performed at $4 . \mathrm{C}$ on a Bio Gel P-60 column $(15 \times 60 \mathrm{~cm})$.

Elution from the P-60 column with $0.05 \mathrm{M}$ ammonium formate at $\mathrm{pH} 5.0$ was the first step of rat $\mathrm{C} 4 \mathrm{a}$ purification. Initially the effluent was monitored by assaying for activity of the combined anaphylatoxins using the guinea pig ileal bioassay. Later the isolated $\mathrm{C} 4 \mathrm{a}$ was radioiodinated with ${ }^{125} \mathrm{I}$ and elution was monitored as radioactivity (see Fig. 1). The fractions containing anaphylatoxin activity were pooled and fractionated further by applying the material to a QAE-Sephadex Q-50 column $(1.8 \times 20 \mathrm{~cm})$, equilibrated with $0.05 \mathrm{M}$ ammonium bicarbonate at $\mathrm{pH} 8.6$ and developed using isocratic elution. This step removed a major portion of the contaminating protein (Fig. 2). The anaphylatoxin-containing pool was finally subjected to chromatography on a Mono $\mathrm{S}$ column. The conditions used to develop the Mono $S$ column are described in the legend to Fig. 3.

Preparation of $\mathrm{C} \mathrm{a}_{\text {des }}$ Arg can be obtained in the same manner as C4a except that the serum carboxypeptidase $N$ inhibitor is not added. The $\mathrm{C} \mathrm{a}_{\mathrm{des} A x}$-containing pools obtained from the Bio Gel
P-60 and then a QAE-Sephadex column was applied to the Mono $S$ column and the elution profile is shown in Fig. 4. These columns were all monitored by ${ }^{125} \mathrm{I}-\mathrm{C}_{4} \mathrm{a}_{\text {des Arg }}$ radioactivity and $280 \mathrm{~nm}$ absorbance. The material in the pool identified as peak $I$ was $C 4 a_{d e s}$ ary.

\section{The electrophoretic behavior of $\mathrm{C} 4 \mathrm{a}$ and $\mathrm{C} 4 \mathrm{a}_{\text {tat }}$ ar}

Disc polyacrylamide gel electrophoresis was carried out on $0.1 \%$ SDS-9\% polyacrylamide gels at pH 7.2 (Weber and Osborn, 1969) and protein bands were visualized by staining with Coomassic bluc.

Electrophoresis on cellulose acetate strips was per formed in $0.075 \mathrm{M}$ barbital buffer at pH 8.6 using a Beckman Model R 101 apparatus at room temp for $30 \mathrm{~min}$ at $200 \mathrm{~V}$, and protein was stained using Amido Black.

\section{Cyanogen bromide cleavage of $\mathrm{C} 4 \mathrm{a}_{\mathrm{den}, \mathrm{A}}$}

$\mathrm{C}_{4} \mathrm{a}_{\text {des Arg }}$ was reduced and alklyated with 4-vinyl pyridine according to Friedman et al. (1970) prior to $\mathrm{CNBr}$ digestion. Pyridylethyl-C4a $\mathrm{Ca}_{\text {des }}$ (PE$\mathrm{C}_{4 \mathrm{a}_{\text {des Arg }}}$ ) was dissolved in $1 \mathrm{ml}$ of $70 \%$ formic acid containing a 300 -fold molar excess of $\mathrm{CNBr}$. After incubation for $24 \mathrm{hr}$ at room temp, the reaction mixture was diluted to $10 \mathrm{ml}$ with cold water and lyophilized. The material was redissolved in $5 \mathrm{ml}$ of water and again lyophilized. The dried material was dissolved in $0.2 \mathrm{ml}$ of water and the CNBr-peptides were separated by reverse phase HPLC on a $\mathrm{C} 4$ column (Vydac 5). The elution conditions used are described in the legend to Fig. 6.

\section{Amino acid and sequence analysis}

Automated Edman degradation was performed on an Applied Biosystems Model 470A. The PTH amino acid derivatives were analyzed by HPLC using an automatic Waters HPLC system.

Amino acid analysis were performed on a Beckman $121 \mathrm{M}$ analyzer. Cysteine residues in $\mathrm{C} 4 \mathrm{a}$ were reduced and alkylated by reaction with 4-vinyl pyridine before amino acid analysis was performed. The PE$\mathrm{C}_{4} \mathrm{a}_{\text {des Arg }}$ or CNBr-digested fragments of PE-C4a $\mathrm{a}_{\text {des Arz }}$ were placed in ignition tubes, vacuum sealed and hydrolyzed at $110^{\circ} \mathrm{C}$ for $24 \mathrm{hr}$ in constant-boiling $\mathrm{HCl}$ containing $1 \%(\mathrm{v} / \mathrm{v})$ phenol.

Determination of the C-terminal amino acid residues of $\mathrm{C} 4 \mathrm{a}$ was accomplished by carboxypeptidase digestion. Rat $\mathrm{C} 4 \mathrm{a}(2 \mathrm{nM})$ was dissolved in $1 \%$ sodium bicarbonate at $\mathrm{pH} 8.0-8.5$ and incubated with $2 \%$ carboxypeptidase $\mathrm{B}(\mathrm{w} / \mathrm{w})$ at $37 \mathrm{C}$. After $5 \mathrm{~min}, 0.1 \mathrm{M}$ citric acid $-0.2 \mathrm{MHCl}$ buffer was added to stop the reaction. Amino acid analysis were performed to detemine the residues released.

Carboxypeptidase $Y$ digestion was performed in $0.05 M$ sodium acetate buffer at $\mathrm{pH} 5.5$ and $37^{\circ} \mathrm{C}$ for $0-2 \mathrm{hr}$ with $4 \%(\mathrm{w} / \mathrm{w})$ enzyme. The reaction was stopped by adding $0.2 M$ citric acid buffer and amino acid analyses were performed. 


\section{Carbohydrate analysis}

Aliquots containing $1.5 \mathrm{nmol}$ of $\mathrm{C}_{4} \mathrm{a}_{\text {des Arg }}$ were loaded on $0.1 \% \operatorname{SDS}-9 \%$ polyacrylamide gels and disc electrophoresis was carried out at pH 7.2 (Weber and Oshorn, 1969). One gel was stained with Coomassie blue for protein and another was fixed in methanol-water-acetic acid $(60: 35: 5)$ and stained for carbohydrate by PAS reagents as described by Kapitany and Zebrowsky (1973).

Deglycosylation of native rat $\mathrm{C} 4 \mathrm{a}$ was accomplished by digestion of $20 \mu \mathrm{g}$ of rat $\mathrm{C} 4 \mathrm{a}$ in $0.2 \mathrm{M}$ sodium phosphate at pH 8.6 using $7.0 \mu \mathrm{l}$ of $\mathrm{N}$ glycanase (260 units $/ \mathrm{ml}$ ) and incubating for $12 \mathrm{hr}$ at $37^{\circ} \mathrm{C}$ (Chu, 1986). The deglycosylated preparation of rat $\mathrm{C} 4 \mathrm{a}$ was analyzed by SDS-PAGE as described above.

\section{Immunoassay analysis}

Munospecific anti-rat $\mathrm{C} 4 \mathrm{a}$ was raised in rabbits by injecting $50 \mu \mathrm{g}$ of rat $\mathrm{C}^{4} \mathrm{a}_{\text {des Arg }}$ in complete Freund's adjuvant into the popliteal lymph nodes. Two and four weeks later the rabbits received intramuscular and subcutaneous injections of $50 \mu \mathrm{g}$ of the antigen with incomplete Freund's adjuvant. One week later the rabbits were bled and antiserum was recovered. Immunodiffusion analyses (Ouchterlony and Nilsson, 1978) of isolated rat C4a, rat C3a (Jacobs et al., 1978) and rat C5a (Cui et al., 1985) were performed using the monospecific anti-rat C4a. Radioimmunoassays according to the procedures described by Hugli and Chenoweth (1981) were developed for rat C3a and rat $\mathrm{C} 5 \mathrm{a}$. Levels of both rat $\mathrm{C} 3 \mathrm{a}$ and $\mathrm{C5a}$ were determined in rat $\mathrm{C} 4 \mathrm{a}$ preparations using the radioimmunoassay technique at a sensitivity of $20-50 \mathrm{ng} / \mathrm{ml}$.

\section{RESULTS}

\section{Purification of rat $C 4 a$ and $C 4 a_{\text {des Arg }}$}

Both intact and des Arg forms of $\mathrm{C} 4 \mathrm{a}$ were recovered from rat sera containing carboxypeptidase $N$ inhibitor and activated by heat-aggregated human IgG. The results of a three-step procedure for purification of $\mathrm{C} 4 \mathrm{a}$ are outlined in Figs 1-3. Gel filtration and QAE-Sephadex chromatography (Figs 1 and 2) result in a separation of rat $\mathrm{C} 4 \mathrm{a}$ from rat $\mathrm{C} 3 \mathrm{a}$ and most other impurities, but it fails to separate the C4a from C5a since both are cationic glycoproteins. Resolution of rat $\mathrm{C} 4 \mathrm{a}$ and $\mathrm{C} 5 \mathrm{a}$ was achieved by employing a Mono S column (Fig. 3). Results of amino acid analysis suggested that material in pools II and IV from the Mono S column was rat $\mathrm{C} 4 \mathrm{a}$ and pools I and III presumably contain rat $\mathrm{CHa}_{\text {des Arg }}$ (sec Fig. 3). Although serum carboxypeptidase $N$ inhibitor was present during complement activation with aggregated $\operatorname{IgG}$, significant activation apparently occurred prior to the addition of IgG based on the level of $\mathrm{C} \mathrm{a}_{\text {des Arg }}$ obtained. Presumably activation is caused both from mixing of serum obtained from several strains of animals and as a result of coagulation enzymes.

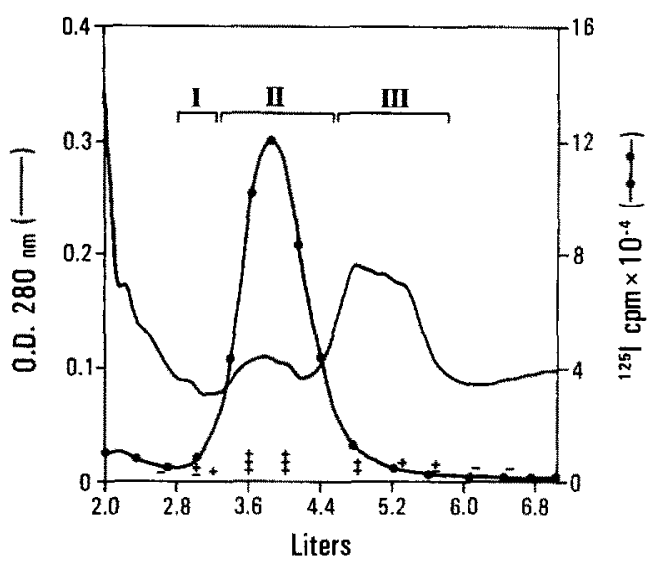

Fig. 1. Gel filtration of soluble material recovered from 21 of complement-activated rat serum after acid precipitation. Separation was performed on a Bio-Gel P60 column $(15 \times 60 \mathrm{~cm})$ equilibrated with $0.1 M$ ammonium formate buffer at pII 5.0. The column was eluted with $0.1 \mathrm{M}$ ammonium formate, $\mathrm{pH} 5.5$, at a flow rate of $135 \mathrm{ml} / \mathrm{hr}$ and fractions of $40 \mathrm{ml}$ were collected. Biological activity was determined by the guinea pig ileal assay. Active fractions (35-80) coincided with radioactivity from $\left[{ }^{125} \mathrm{I}\right] \mathrm{C} 4 \mathrm{a}_{\text {des Arg }}$ that was introduced in the original serum sample. Material in pool II was recovered for chromatography on the OAESephadex column.

Rat plasma drawn into EDTA contains $1.08 \mu \mathrm{g} / \mathrm{ml}$ of $\mathrm{C4a}$ and plasma drawn into heparin has $0.99 \mu \mathrm{g} / \mathrm{ml}$ of $\mathrm{C} 4 \mathrm{a}$ which is $5-10$-fold higher than normal background $\mathrm{C} 4 \mathrm{a}$ levels in human EDTA or

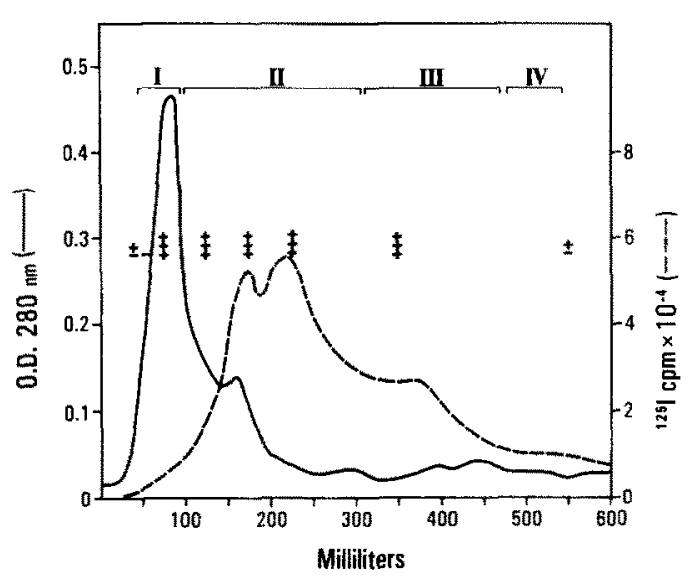

Fig. 2. Chromatography of material in pool II from the Bio Gel P-60 column was performed on a $1.8 \times 20 \mathrm{~cm}$ QAESephadex (Q-50) column equilibrated with $0.05 \mathrm{M}$ ammonium bicarbonate at pH 8.6. Material in pool II collected from Bio Gel P-60 filtration was applied to the QAESephadex column after dialysis, lyophilization and being redissolved in 1-2 $\mathrm{ml}$ of the $\mathrm{pH} 8.6$ buffer. Isocratic elution was performed with $0.05 \mathrm{M}$ ammonium bicarbonate at $\mathrm{pH} 8.6$ at a flow rate of $10-12 \mathrm{ml} / \mathrm{hr}$. Fractions of $2.5 \mathrm{ml}$ were collected and biological activity was determined using the guinea pig ileal assay. Note that C4a and C5a activity was indistinguishable and overlapping at this step. The rat $\mathrm{C} 3 \mathrm{a}$ elutes in pool I as the most cationic of the three anaphylatoxins (Jacobs et al., 1978). 


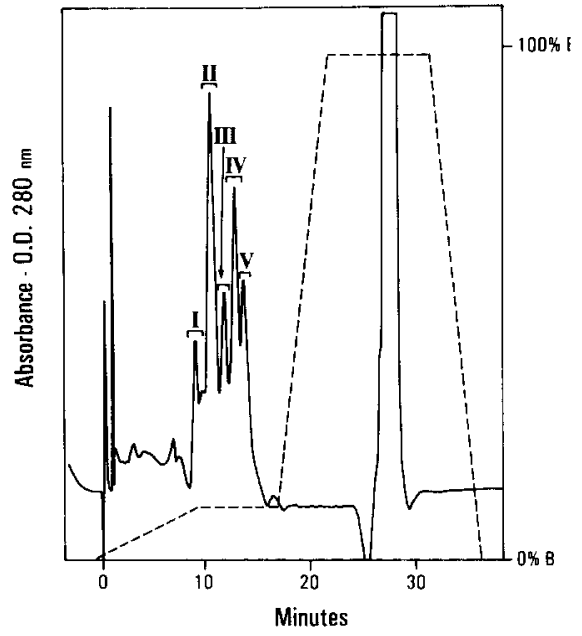

Fig. 3. Chromatography of C4a on a Mono S column. The anaphylatoxin-containing pools II and III from QAESephadex were applied to a Mono S (HR 5/5) column. Solvent A: $0.1 M$ ammonium formate at $\mathrm{pH} 7.0$. Solvent $\mathrm{B}$ : $0.8 \mathrm{M}$ ammonium formate at $\mathrm{pH} 7.0$. A linear gradient was developed over $10 \mathrm{~min}$ from $100 \%$ solvent A to $90 \%$ solvent A containing $10 \%$ solvent $\mathrm{B}$. A $90 \%$ A $/ 10 \%$ B solvent was maintained for $7 \mathrm{~min}$ and then another linear gradient from $10 \%$ solvent B to $100 \%$ solvent $B$ was developed over $5 \mathrm{~min}$. Elution with $100 \%$ solvent $B$ was maintained for 8 additional min and returned to $100 \%$ solvent $\mathrm{A}$. The absorbance setting was 0.02 O.D. units full scale. Both pools II and IV were concluded to contain $\mathrm{C} 4 \mathrm{a}$ material based on amino acid analysis. We speculate that variations in sialic acid content may account for the multiple peaks of $\mathrm{C} 4 \mathrm{a}$.

heparin plasma. The $\mathrm{C} 4 \mathrm{a}$ in rat serum was $7.63 \pm 4.78 \mu \mathrm{g} / \mathrm{ml}(n=48)$ or nearly half of the C4a expected from total conversion of $\mathrm{C} 4$. As in the plasma, we observed nearly 10-fold higher levels of $\mathrm{C} 4 \mathrm{a}$ in fresh rat serum than in human serum. These results indicate that the predominant mechanism of $\mathrm{C} 4$ conversion during plasma or serum collection is initiated by enzymes of the coagulation cascade.

The major peak from a Mono S (Fig. 4) separation of material obtained by activating serum in the absence of carboxypeptidase $N$ inhibitor contains the des Arg derivative of rat $\mathrm{C} 4 \mathrm{a}$. The materials in pool IV from Fig. 3 and in pool I from Fig. 4 are nearly identical based on compositional analysis except for the arginine content (see Table 1). When the material recovered from the Mono $\mathrm{S}$ column was applied to cellulose acetate strip electrophoresis (Fig. 5A), a single stained protein band was revealed indicating that intact $\mathrm{C} 4 \mathrm{a}$ (lane 3) and $\mathrm{C}_{4} \mathrm{a}_{\text {des Arg }}$ (lane 2) were homogencous. Elcctrophoretic bchavior of $\mathrm{C} 4 \mathrm{a}$ on SDS-polyacrylamide gels (Fig. 5B) also shows a single band (gel 3) when stained with Coomassie blue. Positive staining of $\mathrm{C} 4 \mathrm{a}$ in the SDS gels with PASreagent (gel 4) proved that rat $\mathrm{C} 4 \mathrm{a}$, like human $\mathrm{C} 5 \mathrm{a}$ (gels 5 and 6), is a glycoprotein. Preparations of rat $\mathrm{C} 4 \mathrm{a}$ and $\mathrm{C}_{4 \mathrm{a}_{\text {des Arg }}}$ obtained by the three-step isolation procedure were used in all the structural analysis and functional tests described below. Yields of approxi-

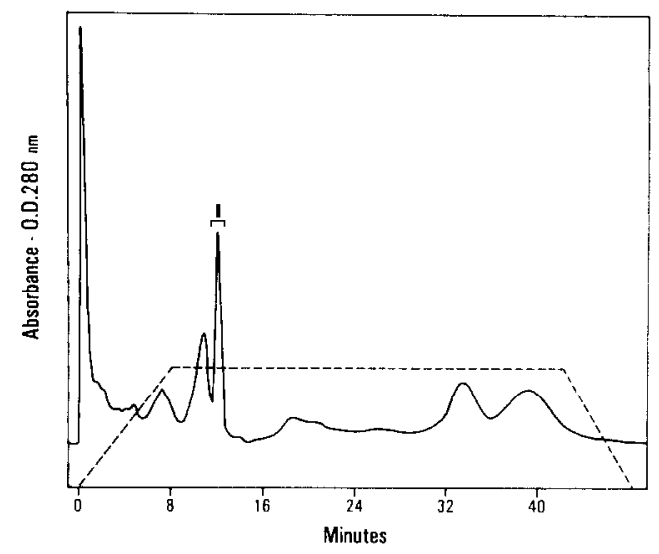

Fig. 4. Chromatography of rat $\mathrm{C}_{4} \mathrm{a}_{\text {des Arg }}$ on a Mono $\mathrm{S}$ column. Serum was activated by aggregated $\operatorname{IgG}$ without serum carboxypeptidase $N$ inhibitor present and the anaphylatoxin-containing pool from Bio Gel P60 and QAESephadex was applied to a Mono S (HR 5/5) column Solvent A: $0.1 M$ ammonium formate at $\mathrm{pH} 7.0$. Solvent B: $0.8 \mathrm{M}$ ammonium formate at $\mathrm{pH} 7.0$. A linear gradient was developed at $1 \mathrm{ml} / \mathrm{min}$ from $100 \%$ solvent A to $27 \%$ solvent $\mathrm{B}$ in $5.4 \mathrm{~min}$ and isocratic elution with $27 \%$ solvent $\mathrm{B}$ was maintained for 35 additional min. Pool I was determined to be rat $C 4 a_{d e s} A_{i}$.

mately $1-2 \mathrm{mg}$ each of $\mathrm{C} 4 \mathrm{a}$ and $\mathrm{C}_{4} \mathrm{a}_{\mathrm{des} \text { Arg }}$ are recovered from 21 of rat serum.

\section{Anaphylatoxin activity of rat $\mathrm{C} 4 \mathrm{a}$}

Both $\mathrm{C} 4 \mathrm{a}$ and $\mathrm{C}_{4} \mathrm{a}_{\text {des Arg }}$ were tested for anaphylatoxin activity. The results of the guinea pig ileal assay are given in Table 2 and only the intact $\mathrm{C} 4 \mathrm{a}$ molecule is spasmogenic. Rat $\mathrm{C}_{4} \mathrm{a}_{\text {des Arg }}$ is inactive at a concentration of up to $10^{-5} M$. Rat $\mathrm{C} 4 \mathrm{a}$ elicits contraction of smooth muscle at a concentration of $0.1-1 \mu M$, or approximately 3 -fold greater activity than that of human $\mathrm{C} 4 \mathrm{a}$. Human $\mathrm{C} 4 \mathrm{a}$ is active at a

Table 1. Amino acid composition of rat $\mathrm{C} 4 \mathrm{a}$ and $\mathrm{C} 4 \mathrm{ades}_{\mathrm{Arg}}$

\begin{tabular}{lcc}
\hline Amino acid & $\begin{array}{c}C 4 \mathrm{a}_{\mathrm{des} A \mathrm{Arg}} \\
\text { (residues/mole) }\end{array}$ & $\begin{array}{c}C 4 \mathrm{a}^{\prime \prime} \\
\text { (residues/mole) }\end{array}$ \\
\hline Lysine & $4.90(5)$ & $4.89(5)$ \\
Arginine & $8.14(8)$ & $9.01(9)$ \\
Aspartic acid & $5.99(6)$ & $6.38(6)$ \\
Threonine & $3.75(4)$ & $3.68(4)$ \\
Serine & $4.26(5)$ & $4.51(5)$ \\
Glutamic acid & $11.23(11)$ & $11.05(11)$ \\
Proline & $5.57(5)$ & $5.54(5)$ \\
Glycine & $3.20(3)$ & $3.02(3)$ \\
Alanine & $8.15(8)$ & $7.86(8)$ \\
Half-cystine & $6.27(6)^{\circ}$ & $6.0(6)^{\circ}$ \\
Valine & $2.00(2)$ & $2.03(2)$ \\
Methionine & $2.05(2)$ & $1.40(2)$ \\
Isoleucine & $1.18(1)$ & $1.09(1)$ \\
Leucine & $5.26(5)$ & $5.12(5)$ \\
Tyrosine & $1.23(1)$ & $1.09(1)$ \\
Phenylalanine & $2.95(3)$ & $3.10(3)$ \\
$\quad$ Total residues: & $(75)^{d}$ & $(76)^{d}$ \\
\hline
\end{tabular}

${ }^{a}$ Rat C4a was from pool IV of the Mono $\mathrm{S}$ column elution shown in Fig, 3 and rat $C 4 a_{\text {des } A r g}$ was from pool $I$ of the Mono $S$ column elution shown in Fig. 4.

${ }^{b}$ Half-cystine was detected as a pyridylethyl-cysteıne derivative.

'Six half-cystines were assumed from $\mathrm{C}_{4} \mathrm{a}_{\mathrm{dcs}} \mathrm{Arg}$ results.

${ }^{d}$ Residues in parentheses were taken from the primary structure analysis. 


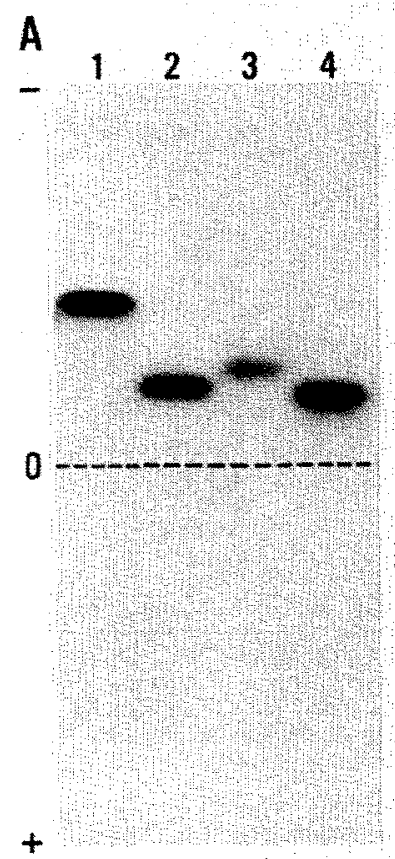

Fig. 5.(A). Microzone electrophoresis of rat C4a (lane 3) and rat $\mathrm{C} \mathrm{a}_{\mathrm{des} \text { Arg }}$ (lane 2) compared with human C3a (lane 1) and human CSa (lane 4). Electrophoresis was performed for $20 \mathrm{~min}$ on cellulose acelate membrane strips at $\mathrm{pH} \mathrm{8.6.}$ The dashed line indicates the origin for sample application.

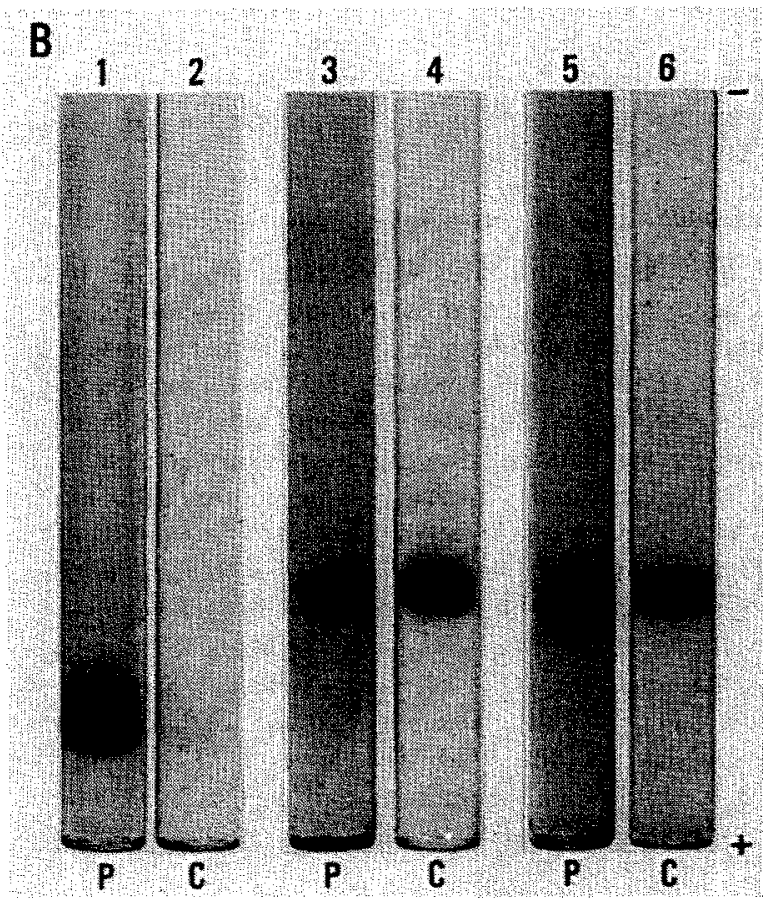

Fig. 5.(B). SDS-polyacrylamide gel electrophoresis of human C3a (gels 1 and 2), rat C4a (gels 3 and 4), human C5a (gels 5 and 6 ) in $9 \%$ acrylamide gels using $0.1 \%$ SDS. Protein was stained by Coomassie blue (left gel of pair) and carbohydrate (right gel of pair) was stained by PAS-reagent.
Table 2. Relative activity of rat $\mathrm{C4a}$, human $\mathrm{C} 4 \mathrm{a}$ and human $\mathrm{C} 3 \mathrm{a}$ in the guinea pig assay

\begin{tabular}{lcc}
\hline Factors & Effective doses & Relative activily \\
Human C3a & $69 \times 10^{9} \mathrm{M}$ & 100 \\
Human C4a & $1-2 \times 10^{-6} \mathrm{M}$ & 0.5 \\
Rat C4a & $0.1 \mathrm{3} \times 10^{-6} \mathrm{M}$ & 1.5 \\
Deglycosylated rat C4a & $0.5-2 \times 10^{-6} \mathrm{M}$ & 1.0 \\
\hline
\end{tabular}

${ }^{a}$ Minimum concentration of factor required to elicit a full con* traction of guinea pig ileal strip in a $2.0 \mathrm{ml}$ bath.

${ }^{\circ}$ Cited from Gorski et at. (1979).

concentration of about $10-20 \mu \mathrm{g} / \mathrm{ml}(1-2 \mu M)$ while human C3a is active at a level of $0.05 \mu \mathrm{g} / \mathrm{ml}(5 \mathrm{nM})$.

Native $\mathrm{C} 4 \mathrm{a}$ was readily deglycosylated by digestion with $N$-glycanase and without a requirement for detergent. When the deglycosylated rat $\mathrm{C} 4 \mathrm{a}$ was electrophoresed either SDS-polyacrylamide gels or on cellulose acetate strips it migrated faster than intact rat $\mathrm{C} 4 \mathrm{a}$ moving with rat $\mathrm{C} 3 \mathrm{a}$, which is a non-glycosylated anaphylatoxin. Deglycosylated rat C4a no longer stained positive with PAS staining and all of the glycosylated material was converted based on visual inspection of the protein staining pattern after electrophoresis. Functional analysis indicated that removal of the oligosaccharide unit from rat $\mathrm{C} 4 \mathrm{a}$ had little influence on the spasmogenic activity of the molecule (see Table 2).

It is important to note that prior addition of human $\mathrm{C} 3 \mathrm{a}$ to the muscle strips blocks rat $\mathrm{C} 4 \mathrm{a}$ contraction, confirming that $\mathrm{C} 3 \mathrm{a}$ and $\mathrm{C} 4 \mathrm{a}$ are crosstachyphylactic factors and are presumed to interact with the same cellular receptors. The fact that C3a blocks contraction of the muscle by $\mathrm{C} 4 \mathrm{a}$ proves that the C4a preparation is devoid of rat C5a, since C5a-induced contractions are not affected by prior exposure to C3a. It is known that C5a is more than 1000 times as active as $\mathrm{C} 4 \mathrm{a}$ on the guinea pig ileum, consequently trace quantities of $\mathrm{C} 5 \mathrm{a}$ in the $\mathrm{C} 4 \mathrm{a}$ preparation would be readily detected in the bioassay.

\section{Amino acid sequence of rat $C 4 a$}

Most of the structural analyses were performed using the des Arg form of rat $\mathrm{C} 4 \mathrm{a}$. The partial $\mathrm{NH}_{2}$-terminal sequence of $\mathrm{PE}-\mathrm{C} 4 \mathrm{a}_{\text {des Arg }}$ was established by automated sequence analysis and these results are presented in Table 3 . This analysis of intact $\mathrm{C4}_{\text {des Arg }}$ provided assignments for 33 of the $\mathrm{NH}_{2}$-terminal residues and identified two methionyl residues in $\mathrm{C}^{2} a_{\operatorname{des} \mathrm{Arg}}$ that are located at positions 28 and 33. From these results it was concluded that $\mathrm{CNBr}$ cleavage would produce a large peptide fragment containing residues $34-75$, as well as the two sequenced fragments $1-28$ and 29-33. The HPLC separation of a $\mathrm{CNBr}$ digest of $\mathrm{PE}-\mathrm{C}_{4} \mathrm{a}_{\text {des Arg }}$ was performed on a $\mathrm{C} 4$ reverse phase column (Vydac 5) which resolved the mixture into two major peaks (1 and II) as shown in Fig. 6.

Amino acid analyses of the material recovered from pools $\mathrm{CNBr} I$ and $\mathrm{CNBr}$ II are shown in Table 4. The compositions of the two peptides are dis- 
Table 3. The $\mathrm{NH}_{2}$-terminal primary structure

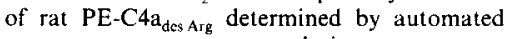
sequence analysis

\begin{tabular}{|c|c|c|}
\hline Cycle & $\begin{array}{c}\text { Residue } \\
\text { Identified }\end{array}$ & $\begin{array}{c}\text { Recovery } \\
\text { (pmole) }\end{array}$ \\
\hline 1 & Asn & 1920 \\
\hline 2 & Val & 1860 \\
\hline 3 & Asn & 1250 \\
\hline 4 & Phe & 2050 \\
\hline 5 & Gin & 1510 \\
\hline 6 & Lys & 1000 \\
\hline 7 & Ala & 1470 \\
\hline 8 & Ile & 1110 \\
\hline 9 & Ser & 100 \\
\hline 10 & Glu & 640 \\
\hline 11 & Lys & 490 \\
\hline 12 & Leu & 700 \\
\hline 13 & Gly & 270 \\
\hline 14 & Gln & 400 \\
\hline 15 & Tyr & 400 \\
\hline 16 & Ser & 430 \\
\hline 17 & Ser & 150 \\
\hline 18 & Pro & 300 \\
\hline 19 & Asp & 150 \\
\hline 20 & Thr & 660 \\
\hline 21 & Lys & 990 \\
\hline 22 & Arg & 120 \\
\hline 23 & PE-Cys ${ }^{h}$ & N.D. \\
\hline 24 & PE-Cys ${ }^{h}$ & N.D. \\
\hline 25 & Gln & 110 \\
\hline 26 & Asp & 70 \\
\hline 27 & Gly & 50 \\
\hline 28 & Met & 80 \\
\hline 29 & Thr & 40 \\
\hline 30 & Lys & 30 \\
\hline 31 & Leu & 80 \\
\hline 32 & Pro & 120 \\
\hline 33 & Met & 60 \\
\hline
\end{tabular}

tinctive and the composition of peptide from peak I clearly indicates that it represents residues 34-75 (peptide $\mathrm{CNBr}-\mathrm{II}$ ), a fragment from the $\mathrm{COOH}$ terminal portion of $\mathrm{C}^{4} \mathrm{a}_{\mathrm{des}} \mathrm{Arg}$. A sample of $\mathrm{CNBr}$ II was subjected to 42 cycles of automatcd Edman degradation and assignment of the sequence of the CN II peptide is given in Table 5.

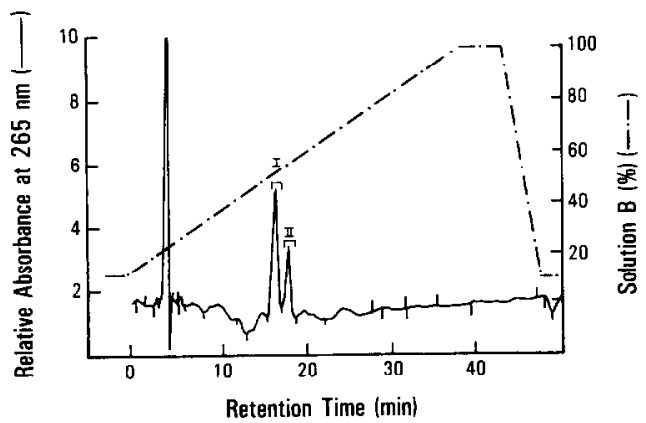

Fig. 6. Chromatography of the $\mathrm{CNBr}$ peptides derived from rat PE-C4a $a_{\text {des Arg }}$ on a Vydac $5 \mathrm{C} 4$ column. Solvent A: $0.1 \%$ TFA in water. Solvent B: $0.03 \%$ TFA in acetonitrile. A linear gradient was programmed from $10 \%$ solvent B to $100 \%$ solvent B over $45 \mathrm{~min}$ at a flow rate of $1 \mathrm{ml} / \mathrm{min}$. Peak I (contained fragments 34-75 of rat $\mathrm{CHa}_{\text {des Arg }}$ (peptide $\mathrm{CNBr}$ II) and Peak II contained fragments $1-28$ and $1-33$ based on amino acid analysis.
Table 4. Amino acid analysis of peptides isolated from $\mathrm{CNBr}$ cleavage of rat $\mathrm{PE}-\mathrm{C} 4 \mathrm{a}_{\mathrm{des}} \mathrm{Arg}$

\begin{tabular}{llc}
\hline Amino acid & $\begin{array}{c}\text { CNBr-I } \\
\text { (residues/mole) }\end{array}$ & $\begin{array}{c}\text { CNBr-II } \\
\text { (residues/mole) }\end{array}$ \\
Lysine & $3.27(3-4)^{a}$ & $1.13(1)$ \\
Arginine & $1.32(1)$ & $6.35(7)$ \\
Aspartic acid & $3.40(4)$ & $2.07(2)$ \\
Threonine & $1.46(1-2)$ & $1.86(2)$ \\
Serine & $2.20(3)$ & $1.72(2)$ \\
Glutamic acid & $4.62(4)$ & $7.13(7)$ \\
Proline & $2.04(2)$ & $2.93(3)$ \\
Glycine & $2.03(2)$ & $1.37(1)$ \\
Alanine & $1.69(1)$ & $6.74(7)$ \\
Half-cystine & $\mathrm{ND}(2)^{h}$ & $\mathrm{ND}(4)^{h}$ \\
Valine & $1.07(1)$ & $0.99(1)$ \\
Methionine & $0.14(1-2)$ & $0.05(0)$ \\
Isoleucine & $0.88(1)$ & $0.08(0)$ \\
Leucine & $2.04(1-2)$ & $3.14(3)$ \\
Tyrosine & $0.86(1)$ & $0.0(0)$ \\
Phenylalanine & $1.14(1)$ & $1.93(2)$ \\
\multicolumn{1}{c}{ Total residues: } & $28-33^{\circ}$ & 42 \\
\hline
\end{tabular}

"The number in parentheses were based on expected values from the primary structure analysis of rat $\mathrm{C} 4 \mathrm{a}$

'Identified as PE-cysteine but not quantitated.

'Composition suggests mixture of fragments $\mathbf{I}-28$ and 13.

Short-term digestion of $2 \mathrm{nmol}$ of $\mathrm{C} 4 \mathrm{a}$ with carboxypeptidase-B (CpB) indicated that $1.07 \mathrm{~mol}$ of arginine was released per mole of C4a. Carboxypeptidase $\mathrm{Y}(\mathrm{CpY})$ digestion of $2 \mathrm{nmol}$ of $\mathrm{C4a}_{\text {des Arg }}$ released the following residues expressed as moles per

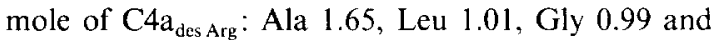
Gln 0.47 . These results gave further evidence that the $\mathrm{COOH}$-terminal sequence of rat $\mathrm{C} 4 \mathrm{a}$ is Gln-Ala-Gly-I eu-Ala-Arg.

Results from the partial $\mathrm{NH}_{2}$-terminal sequence analysis of PE-C4a des Arg and the $\mathrm{CNBr}$ fragment $\mathrm{C} 4 \mathrm{a}$ 34-75, combined with the amino acid analyses of residues released from $\mathrm{C} 4 \mathrm{a}$ by $\mathrm{CpB}$ and by $\mathrm{CpY}$, provides a complete primary structure for rat $\mathrm{C} 4 \mathrm{a}$ (Fig. 7).

\section{Immunoassays for rat $\mathrm{C} 4 \mathrm{a}$}

The rabbit anti-rat $\mathrm{C} 4 \mathrm{a}$ detected only $\mathrm{C} 4 \mathrm{a}$ by Ouchterlony immunodiffusion analyses and no crossreactivity with purified rat $\mathrm{C} 3 \mathrm{a}$ or $\mathrm{C} 5 \mathrm{a}$ was observed. These results not only indicate that rat $\mathrm{C} 4 \mathrm{a}$ is free of $\mathrm{C} 3 \mathrm{a}$ and $\mathrm{C} 5 \mathrm{a}$, but suggest that these molecules share no common epitopes. Radioimmunoassay analysis is a more sensitive procedure than immunodiffusion and provides a quantitative indication of the levels of contamination in rat $\mathrm{C} 4 \mathrm{a}$ by $\mathrm{C} 3 \mathrm{a}$ or $\mathrm{C} 5 \mathrm{a}$. Radioimmunoassay for rat $\mathrm{C} 3 \mathrm{a}$ and $\mathrm{C} 5 \mathrm{a}$ were each negative when the pool of rat $\mathrm{C} 4 \mathrm{a}$ form the Mono $\mathrm{S}$ column containing $1 \mathrm{mg} / \mathrm{ml}$ of rat $\mathrm{C} 4 \mathrm{a}$ was tested. Since the levels of sensitivity detecting $\mathrm{C} 3 \mathrm{a}$ and for $\mathrm{C} 5 \mathrm{a}$ using this assay procedure is in the range of $20-50 \mathrm{ng} / \mathrm{ml}$, we conclude that contamination of rat $\mathrm{C} 4 \mathrm{a}$ by $\mathrm{C} 3 \mathrm{a}$ or C5a is less than $0.002-0.005 \%$.

\section{DISCUSSION}

Rat $\mathrm{C} 4 \mathrm{a}$ can be purified from rat serum activated by heat-aggregated $\mathrm{IgG}$ in the presence of a serum carboxypeptidase $N$ inhibitor. However, a significant 
Table 5. Automated sequence analysis of peptide $\mathrm{CNBr}-\mathrm{II}$ from rat

\begin{tabular}{|c|c|c|c|}
\hline \multicolumn{4}{|c|}{ PE-C4a $a_{\text {des Arg }}$} \\
\hline Cycles & $\begin{array}{l}\text { Assigned residue } \\
\text { position }\end{array}$ & $\begin{array}{l}\text { Amino acid } \\
\text { identified }\end{array}$ & $\begin{array}{c}\text { Recovery }^{a} \\
\text { (pmole) }\end{array}$ \\
\hline 1 & 34 & Ala & 3630 \\
\hline 2 & 35 & Arg & 3000 \\
\hline 3 & 36 & Thr & 710 \\
\hline 4 & 37 & PE-Cys ${ }^{h}$ & N.D. \\
\hline 5 & 38 & Glu & 1310 \\
\hline 6 & 39 & Gln & 1660 \\
\hline 7 & 40 & Arg & 320 \\
\hline 8 & 41 & Ala & 1871 \\
\hline 9 & 42 & Ala & 1730 \\
\hline 10 & 43 & Arg & 460 \\
\hline 11 & 44 & Val & 1620 \\
\hline 12 & 45 & Pro & 1360 \\
\hline 13 & 46 & Gln & 1020 \\
\hline 14 & 47 & Pro & 1310 \\
\hline 15 & 48 & Ala & 1530 \\
\hline 16 & 49 & PE-Cys ${ }^{b}$ & N.D. \\
\hline 17 & 50 & Arg & 230 \\
\hline 18 & 51 & Giu & 1050 \\
\hline 19 & 52 & Pro & 730 \\
\hline 20 & 53 & Phe & 2310 \\
\hline 21 & 54 & Leu & 720 \\
\hline 22 & 55 & Ser & 80 \\
\hline 23 & 56 & PE-Cys ${ }^{b}$ & N.D. \\
\hline 24 & 57 & PE-Cys ${ }^{h}$ & N.D. \\
\hline 25 & 58 & Lys & 320 \\
\hline 26 & 59 & Phe & 390 \\
\hline 27 & 60 & Ala & 470 \\
\hline 28 & 61 & Glu & 170 \\
\hline 29 & 62 & Asp & 140 \\
\hline 30 & 63 & Leu & 360 \\
\hline 31 & 64 & Arg & 250 \\
\hline 32 & 65 & Arg & 150 \\
\hline 33 & 66 & $(\mathrm{X})^{c}$ & N.D. \\
\hline 34 & 67 & Gin & 210 \\
\hline 35 & 68 & Thr & 90 \\
\hline 36 & 69 & Arg & 70 \\
\hline 37 & 70 & Ser & 20 \\
\hline 38 & 71 & Gln & 80 \\
\hline 39 & 72 & Ala & 90 \\
\hline 40 & 73 & Gly & 40 \\
\hline 41 & 74 & Leu & 40 \\
\hline 42 & 75 & Ala & 50 \\
\hline
\end{tabular}

${ }^{a}$ Recovery was calculated based on 4.3 nmole of peptide $\mathrm{CNBr}-\mathrm{Il}$ ${ }^{h} \mathrm{PE}$-cysteine was positively identified but recovery was not quantitated.

${ }^{c}(\mathrm{X})$ indicates that residue was not identified. quantity of rat $\mathrm{C}_{4} \mathrm{a}_{\text {des Arg }}$ is also obtained from serum activated in the presence of the potent carboxypeptidase inhibitor. We presume that this $\mathrm{C} 4$ conversion occurs because serum collected from different strains of rats is mixed and heterologous blood group antigen-antibody complexes can activate $\mathrm{Cl}$. In addition, coagulation enzymes in rat blood contribute more to $\mathrm{C} 4$ conversion than in human blood based on relative $\mathrm{C} 4 \mathrm{a}$ levels in plasma and serum. Yields of intact $\mathrm{C} 4 \mathrm{a}$, when carboxypeptidase inhibitor was added to rat serum (see Fig. 3) prior to activation by aggregated IgG, suggests that approximately half of the $\mathrm{C} 4$ escapes conversion by coagulation enzymes or from $\mathrm{C} 1$ activated by endogenous immune complex formation during blood processing.

Purity of rat $\mathrm{C} 4 \mathrm{a}$ and the $\mathrm{C} 4 \mathrm{a}_{\text {des Arg }}$ derivative obtained by a three-step isolation procedure was examined by high resolution electrophoresis techniques. Electrophoretic separations of $\mathrm{C} 4 \mathrm{a}$ $\left(\mathrm{C} \mathrm{a}_{\text {des Arg }}\right)$ by size or charge each indicated a single component. Sensitive radioimmunoassays that were specific for rat $\mathrm{C} 3 \mathrm{a}$ or rat $\mathrm{C5}$ a detected neither factor in the $\mathrm{C} 4 \mathrm{a}$ preparation. Based on the combined characterization results, the $\mathrm{C} 4 \mathrm{a}$ fraction from the Mono $\mathbf{S}$ column was judged homogeneous. Functional and immunologic characterizations confirmed that rat $\mathrm{C} 4 \mathrm{a}$ was free of $\mathrm{C} 5 \mathrm{a}(<0.1 \%)$, a glycoprotein of similar size and charge.

Rat $\mathrm{C} 4 \mathrm{a}$ is a glycoprotein with 76 amino acid residues and a molecular weight estimated from SDS-gels at 11,200, based on human C5a (Fernandez and Hugli, 1978). Determination of the complete amino acid sequence of ral $\mathrm{C} 4 \mathrm{a}$ permits a comparison of this molecule with that of human C4a (Moon et al., 1981), bovine C4a (Smith et al., 1982) and mouse C4a (Nonaka et al., 1984). As shown in Fig. 8, the sequence of rat $\mathrm{C} 4 \mathrm{a}$ indicates a $93.4 \%$ homology

1

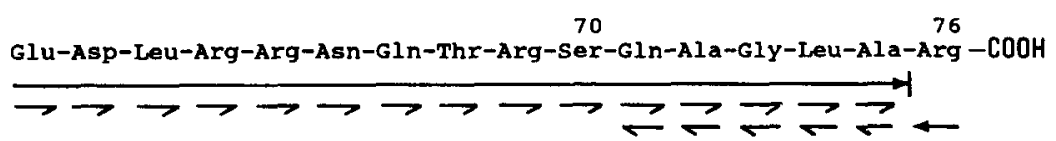

Fig. 7. The complete amino acid sequence for rat $\mathrm{C} 4 \mathrm{a}$. The $N$-terminal 33 residues were identified by automated sequence analysis of $\mathrm{PE}-\mathrm{C} 4 \mathrm{a}_{\text {des } A r g}$. Residues 34-75 were identified by automated sequence analysis of CNBr II (--). Residues released by carboxypeptidase B (---) and Y (---) were designated by the arrows. Asn at position 66 was not identified but was assigned based on the amino acid composition of $\mathrm{CNBr} I$ and the assumption that this was the oligosaccharide attachment site in C4a. 


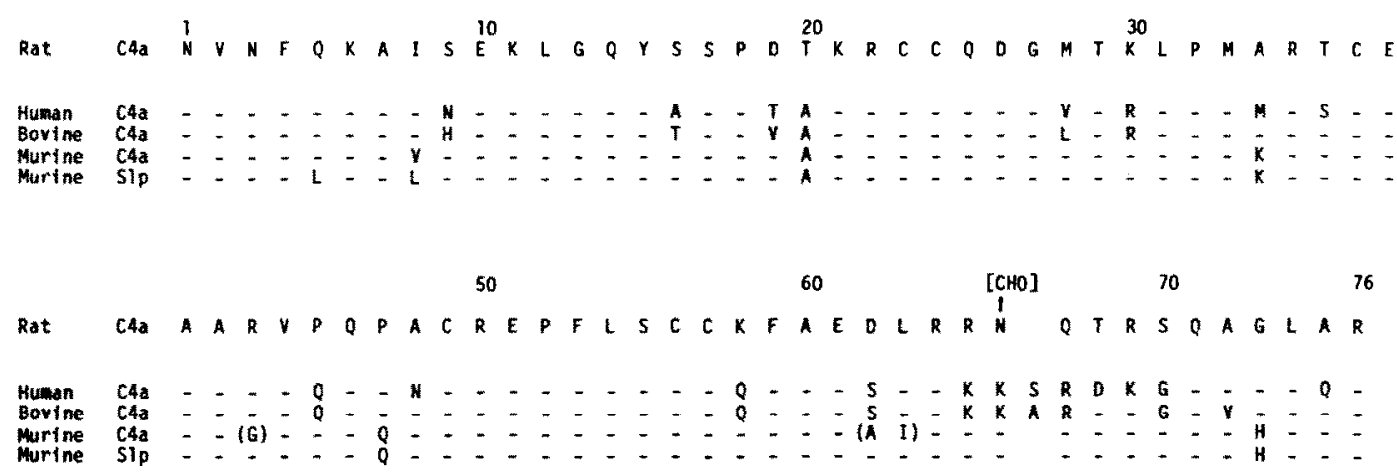

Fig. 8. Comparison of the rat $\mathrm{C} 4 \mathrm{a}$ amino acid sequence with that of human $\mathrm{C} 4 \mathrm{a}$, hovine $\mathrm{C4} 4 \mathrm{a}$, mouse $\mathrm{C} 4 \mathrm{a}$ and mouse Slp. Dashes indicate homology with the rat $\mathrm{C} 4 \mathrm{a}$ sequence. One deletion is positioned between residues 66 and 67 in both rat and mouse sequences compared with human and bovine $\mathrm{C} 4 \mathrm{a}$ molecules based on maximal homology for neighboring residues. Note that rat $\mathrm{C} 4 \mathrm{a}$, mouse $\mathrm{C} 4 \mathrm{a}$ and mouse Slp contain 76 residues while human and bovine C4a each contain 77 residues. The C5a and Slp sequences were deduced from cDNA clones of C4 obtained from B10.WR mice. Residues in parentheses identify differences in mouse $\mathrm{C} 4 \mathrm{a}$ sequences deduced from a $\mathrm{C4} \mathrm{cDNA}$ clone obtained from another inbred strain of mice (FM).

between rat $\mathrm{C} 4 \mathrm{a}$ and mouse $\mathrm{C} 4 \mathrm{a}$ as deduced from the cDNA sequence of a clone from the B10.WR strain of mice (Sepich et al., 1985). Only five amino acid replacements occur between isolated rat $\mathrm{C} 4 \mathrm{a}$ and the deduced sequence of mouse C4a from B10.WR $\left(\mathrm{C}^{\mathrm{W} 7}\right)$ mice. Another deduced mouse $\mathrm{C} 4$ sequence was obtained from a Japanese inbred mouse strain FM (Nonaka et al., 1984) and the $\mathrm{C} 4$ a region in $\mathrm{C}^{\mathrm{M}}$ contains eight amino acid replacements (identified in parentheses in Fig. 8) compared with the rat $\mathrm{C} 4 \mathrm{a}$ sequence. These results would indicate that the $\mathrm{C}_{4}{ }^{\mathrm{W}} 7$ is more like wild-type than is $\mathrm{C} 4^{\mathrm{FM}}$ based on the comparison with rat $\mathrm{C} 4 \mathrm{a}$.

A $75 \%$ homology exists between the rat and human $\mathrm{C} 4 \mathrm{a}$ molecules, including six cysteinyl residues and a functionally essential $\mathrm{COOH}$-terminal arginyl residue. A deletion of one residue exists in rat and mouse $\mathrm{C} 4 \mathrm{a}$ when compared with the human $\mathrm{C} 4 \mathrm{a}$ molecule. We have placed the deletion between positions 66 and 67 in the rat C4a based on maximal homology between flanking sequences. Comparison of the rat $\mathrm{C} 4 \mathrm{a}$ sequence with human $\mathrm{C} 5 \mathrm{a}$ indicates that an unassigned residue located at position 66 in rat $\mathrm{C} 4 \mathrm{a}$ corresponds with the oligosaccharide binding site at position 63 in human C5a. It was therefore concluded that the glycosylation site near the $C$ terminus of rat $\mathrm{C} 4 \mathrm{a}$ is analogous to that in human C5a. Furthermore, the deduced Asn-X-Thr sequence of residues $66-68$ in rat $C 4 a$ represents the only conventional oligosaccharide attachment site in the molecule. $\Lambda$ similar glycosylation site exists in mouse $\mathrm{C} 4 \mathrm{a}$ and mouse Slp; however it is unknown whether the mouse proteins are glycosylated.

Inactivity of rat $\mathrm{C}_{4} \mathrm{a}_{\text {des } \mathrm{Arg}}$ indicates that rat $\mathrm{C} 4 \mathrm{a}$, like all other $\mathrm{C} 3 \mathrm{a}$ and $\mathrm{C} 4 \mathrm{a}$ anaphylatoxins characterized to date, maintains a strict requirement of a C-terminal arginyl residue for biological activity. The biologic activity of rat $\mathrm{C} 4 \mathrm{a}$ is somewhat greater than human $\mathrm{C} 4 \mathrm{a}$ in the guinea pig ileal assay. Although activity of a synthetic C-terminal analog peptide of rat C4a (e.g. AGLAR) is more similar to the human C3a pentapeptide LGLAR (Hugli et al., 1983) than it is to human C4a analog pentapeptide AGLQR, the spasmogenic properties of rat $\mathrm{C} 4 \mathrm{a}$ compare more closely with human $\mathrm{C} 4 \mathrm{a}$ than with $\mathrm{C} 3 \mathrm{a}$. The rat $\mathrm{C} 4 \mathrm{a}$ C-terminal pentapeptide AGLAR is between 10 and $25 \%$ as active as human C3a LGLAR. Based on the fact that the rat $C 4 a$ pentapeptide AGLAR is more than 100-fold more active as the human $\mathrm{C} 4 \mathrm{a}$ peptide AGLQR, it remains inexplicable why rat $\mathrm{C} 4 \mathrm{a}$ is so poorly active compared with human $\mathrm{C} 3 \mathrm{a}$. Obviously, the conformation of the $\mathrm{C}$-terminal portion of $\mathrm{C} 4 \mathrm{a}$ is as important for function as has been demonstrated for C3a (Lu et al., 1984). The fact that numerous residue substitutions occur near the functionally important $\mathrm{C}$-terminus in rat, bovine and human $\mathrm{C} 4 \mathrm{a}$ as compared to $\mathrm{C} 3$ a may explain the unexpectedly low spasmogenic activity of C4a molecules.

We examined whether the carbohydrate moiety of rat $\mathrm{C} 4 \mathrm{a}$ is somehow influencing expression of its biological activity. The composition of the carbohydrate moiety in rat $\mathrm{C} 4$ a has yet to be determined; however the functional role appears not to be a major influence since enzymatic removal of the oligosaccharide unit resulted in no significant enhancement or reduction of $\mathrm{C} 4 \mathrm{a}$ activity.

Since the rat is a popular experimental model for immune disease, the ability to monitor classical pathway activation in these animals may prove to be a valuable assay system. We and others have demonstrated that monitoring anaphylatoxin levels in human body fluids has been useful in correlating complement involvement with numerous discase processes (Chenoweth et al., 1981; Chenoweth, 1984; Hugli and Chenoweth, 1981). The rat antigen C4a should prove equally useful as an indicator of classical pathway activation in this animal model. Preliminary evidence suggests that the radioimmunoassay 
methods of Gorski (1981) for quantitating human $\mathrm{C} 4 \mathrm{a}$ in physiologic fluids may be adaptable for measuring $\mathrm{C} 4$ conversion in bodily fluids from the rat. Such measurements are valuable in assessing the role of complement in experimental models of immune disease.

Acknowledgements - We thank Marleen S. Kawahara for providing the human C5a and Janet L. Wagner for performing the radioimmunoassays. We wish to thank Ellye Lukaschewsky for her assistance in preparing this manuscript. This work was supported by grants Al17354, HL16411 and HL25658 from the U.S. Public Health Service. This is publication number 5166 IMM from the Department of Immunology, Research Institute of Scripps Clinic, La Jolla, CA 92037, U.S.A.

\section{REFERENCES}

Chenoweth D. E. (1984) Complement activation during hemodialysis: clinical observations, proposed mechanisms, and theoretical implications. Ariff. Organs 8, 281-287.

Chenoweth D. E., Stewart R. W., Cooper S. W., Blackstone E. H., Kirklin J. W. and Hugli T. E. (1981) Complement activation during cardiopulmonary bypass: evidence for generation of C3a and C5a anaphylatoxins. N. Engl. J. Med. 384, 497-503.

Chu F. K. (1986) Requirement of clcavage of high mannose oligosaccharide in glycoproteins by peptide $N$-glycosidase F. J. biol. Chem. 261, 172-177.

Cochrane C. G. and Müller-Eberhard H. J. (1968) The derivation of distinct anaphylatoxin activities from the third and fifth components of human complement. J. exp. Med. 127, 371-380.

Cui L.-X., Ferreri K. and Hugli T. E. (1985) Characterization of rat $\mathrm{C} 5 \mathrm{a}$, a uniquely active spasmogen. XIth International Complement Workshop, Miami, Florida, 3-5 November 1985. Complement 19.

Fernandez N. H. and Hugli T. E. (1978) Primary structural analysis of the polypeptide portion of human C5a anaphylatoxin. I. Polypeptide sequence determination and assignment of the oligosaccharide attachment site in C5a. J. biol. Chem. 253, 6955-6964.

Friedman M., Krull L. H. and Cavins J. F. (1970) The chromatographic determination of cysteine and cysteine residues in proteins as $S$ - $\beta$-(4-pyridylethyl) cysteine. $J$. biol. Chem. 245, 3868-3871.

Gerard C. and Hugli T. E. (1981) Identification of the classical anaphylatoxin as the des Arg C5a molecule: evidence of a modulator role of the oligosaccharide role for the unit in human des-Arg ${ }^{74}-\mathrm{C}$ Sa. Proc. natn. Acad. Sci. U.S.A. 78, 1833-1837.

Gorski J. P. (1981) Quantitation of human complement fragment in $\mathrm{C4}_{\mathrm{a}}$ in physiological fluids by competitive inhibition radioimmunoassay. J. Immun. Meth. 47, 61-73.

Gorski J. P., Hugli T. E. and Müller-Eberhard H. J. (1979)
C4a: the third anaphylatoxin of the human complement system. Proc. natn. Acad. Sci. U.S.A. 76, 5299-5302.

Hugli T. E. (1984) Structure and function of the anaphylatoxins. Springer Semin. Immunopathol. 7, 193-219.

Hugli T. E. and Chenoweth D. E. (1981) Biologically active peptides of complement: techniques and significance of $\mathrm{C} 3 \mathrm{a}$ and $\mathrm{C} 5 \mathrm{a}$ measurements. In: Immunoassays: Clinical Laboratory Techniques for the 1980s (Edited by Nakamura R. M., Ditto W. R., Tucker E. S. III), Vol. 4, pp. 443-460. Alan R. Liss, New York.

Hugli T. E., Vallota E. H. and Müller-Eberhard H. J. (1975) Purification and partial characterization of human and porcine C3a anaphylatoxin. $J$. hiol. Chem 250, 1472-1478.

Hugli T. E., Gerard C., Kawahara M., Scheetz M. E., Barton R., Briggs S., Koppel G. and Russell S. (1982) Isolation of three anaphylatoxins from complementactivated human serum. Molec. Cell. Biochem. 41, 59-66, 1982.

Hugli T. E., Kawahara M. S., Unson C. G., Molinor R. L. and Erickson B. W. (1983) The active site of human C4a anaphylatoxins. Molec. Immun. 20, 637-645.

Jacobs J. W., Rubin J. S., Hugli T. E., Bogardt R. A., Mariz. I. K., Danieis J. S., Daughaday W. H. and Bradshaw R. A. (1978) Purification characterization, and amino acid sequence of rat anaphylatoxin (C3a). Biochemistry 17, $503 \mathrm{I}-5038$.

Kapitany R. A. and Zebrowski E. J. (1973) A high resolution PAS stain for polyacrylamide gel electrophoresis. Anal. Biochem. 56, 361-369.

Lu Z-xian, Fok K. F., Erickson B. W. and Hugli T. E. (1984) Conformational analysis of $\mathrm{COOH}$-terminal fragments of human $\mathrm{C} 3 \mathrm{a}$ : evidence of ordered conformation in an active monocosapeptide. J. biol. Chem. 259, 7367-7370.

Moon K. E., Gorski J. P. and Hugli T. E. (1981) Complete primary structure of human $\mathrm{C} 4 \mathrm{a}$ anaphylatoxin. $J$. biol. Chem. 256, 8685-8692.

Nonaka M., Takahashi M., Natsuume-Sakai S., Nonaka M., Tanaka S., Shimizu A. and Honjo T. (1984) Isolation of cDNA clones specifying the fourth component of mouse complement and its isotypes, sex-limited protein. Proc. natn. Acad. Sci. U.S.A. 81, 6822-6826.

Ouchterlony O. and Nilsson L.- $\AA$. (1978) Immunodiffusion and immunoelectrophoresis. In Handbook of Experimental Immunology (Edited by Weir D. M.), 3rd edn, Vol. 1, pp. 19.1-19.44. Blackwells, Oxford.

Sepich D. S., Noonan D. J. and Ogata R. T. (1985) Complete cDNA sequence of the fourth component of murine complement. Proc. natn. Acad. Sci. U.S.A. 82, 5895-5899.

Smith M. A., Gerrie L. M., Dunbar B. and Fothergill J. E. (1982) Primary structure of bovine complement activation fragment C4a, the third anaphylatoxin. Biochem. J. 207, 253.

Weber K. and Osborn M. (1969) The reliability of molecular weight determinations by dodecyl sulfate-polyacrylamide gel electrophoresis. J. biol. Chem. 244, 4406-4412. 